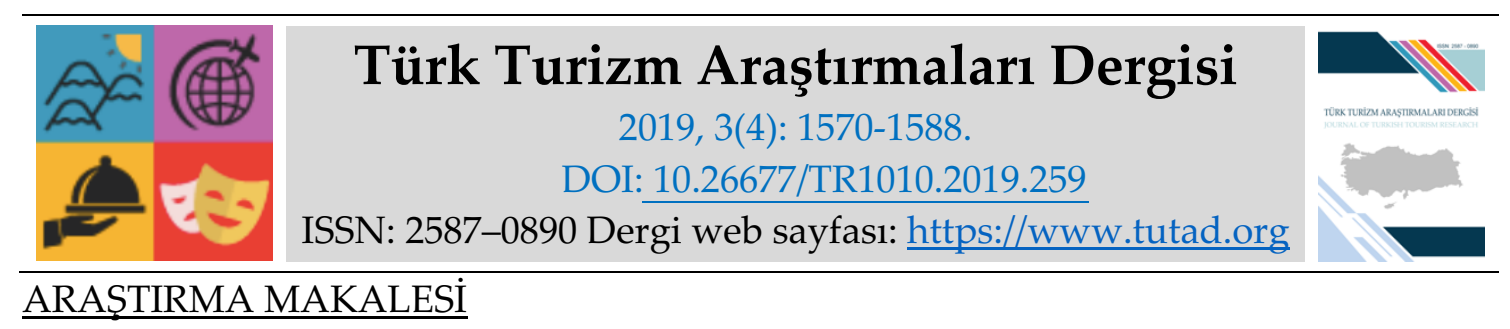

\title{
Algılanan Örgütsel Desteğin Örgütsel Özdeşleşmeye ve İşten Ayrılma Niyetine Etkisi: Afyonkarahisar Örneği*
}

Dr. Öğr. Üyesi Gonca KILIÇ, Afyon Kocatepe Üniversitesi, Turizm Fakültesi, Afyonkarahisar, eposta: kilicgonca@aku.edu.tr ORCID: https://orcid.org/0000-0002-8221-4808

Merve GÜLEN, Bilim Uzmanı, Afyon Kocatepe Üniversitesi, Sosyal Bilimler Enstitüsü, Afyonkarahisar, e-posta: merve bolu @hotmail.com

ORCID: https://orcid.org/0000-0002-9270-4755

Öz

Bu çalışmanın amacı otel işletmelerinde çalışanlarının, örgütsel destek algıları, örgütsel özdeşleşme düzeyleri ve işten ayrılma niyetleri arasındaki ilişki düzeyinin belirlenmesidir. Çalışmada, konuyla ilgili olarak anket tekniği kullanılarak otel işletmeleri çalışanlarının görüşleri alınmıştır. Araştırmanın evrenini, Afyonkarahisar ilinde faaliyet gösteren beş yıldızlı otel işletmesi çalışanları oluşturmakta olup toplam 407 adet çalışanın anketi değerlendirmeye alınmıştır. Katılımcıların ankete ilişkin verdikleri cevaplar; faktör analizi, güvenirlik analizi, yüzde, frekans ve aritmetik ortalama değerleri, korelasyon analizi ve regresyon analizi ile çözümlenmiştir. Elde edilen bulgulara göre beş yıldızlı otel işletmesi çalışanlarının algılanan örgütsel destek düzeyleri ile örgütsel özdeşleşme düzeyleri arasında pozitif yönlü orta düzeyde anlamlı bir ilişki olduğu saptanmıştır. Katılımcıların algilanan örgütsel destek düzeyleri ile işten ayrılma niyeti arasında ise yüksek düzeyde negatif yönlü anlamlı bir ilişki olduğu tespit edilmiştir. Bununla birlikte, yapılan basit doğrusal regresyon analizi sonucunda beş yıldızlı otel işletmeleri çalışanlarının örgütsel destek algılarının örgütsel özdeşleşme düzeylerine pozitif yönlü anlamlı bir etkisi olduğu ayrıca çalışanların örgütsel destek algı düzeylerinin ise işten ayrılma niyetleri üzerine negatif yönlü anlamlı bir etkisi olduğu tespit edilmiştir.

*Bu çalışma Afyon Kocatepe Üniversitesi BAPK birimi tarafından desteklenmiştir.

Anahtar Kelimeler: Algılanan Örgütsel Destek, Örgütsel Özdeşleşme, İşten Ayrılma Niyeti, Beş Yıldızlı Otel İşletmeleri, Afyonkarahisar.

Makale Gönderme Tarihi: 29.07.2019

Makale Kabul Tarihi: 06.10.2019

\section{Önerilen Atıf:}

Kılıç, G. ve Gülen, M. (2019). Algılanan Örgütsel Desteğin Örgütsel Özdeşleşmeye ve İşten Ayrılma Niyetine Etkisi: Afyonkarahisar Örneği, Türk Turizm Araştırmaları Dergisi, 3(4): 1570-1588.

(c) 2019 Türk Turizm Araştırmaları Dergisi. 


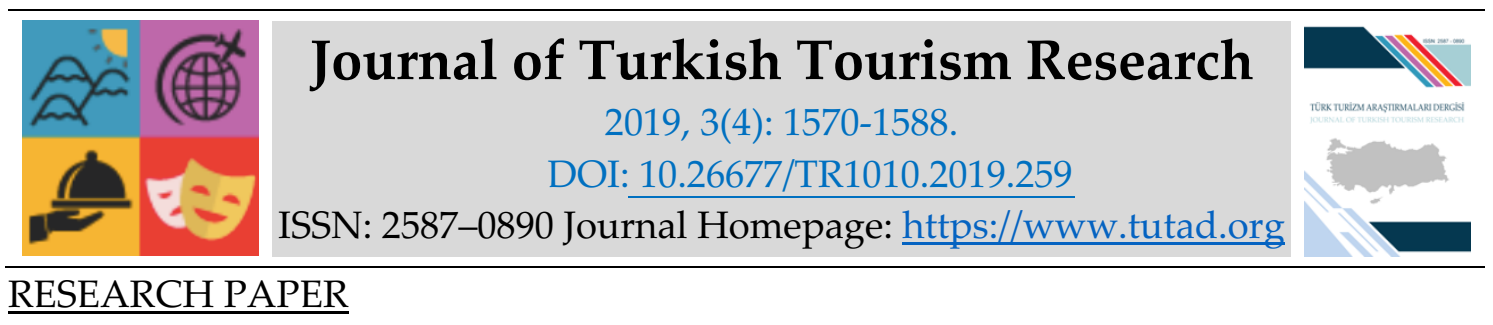

\title{
The Effect of Perceived Organizational Support on Organizational Identification and Intention to Leave: The Case of Afyonkarahisar
}

Ass. Prof. Dr. Gonca KILIÇ, Afyon Kocatepe University, Faculty of Tourism, Afyonkarahisar, e-mail: kilicgonca@aku.edu.tr ORCID: https://orcid.org/0000-0002-8221-4808

Merve GÜLEN, MSc., Afyon Kocatepe University, Institute of Social Sciences, Afyonkarahisar, email: merve_bolu@ @hotmail.com

ORCID: https://orcid.org/0000-0002-9270-4755

\begin{abstract}
The aim of this study is to determine the level of relationship between hotel employees' organizational support perceptions, organizational identification levels and intention to leave. In this study, opinions of hotel employees were taken by questionnaire technique. The population of the research consists of five-star hotel employees working in Afyonkarahisar province and a total of 407 surveys were taken into consideration. Participants' responses were analyzed with factor analysis, reliability analysis, percentage, frequency and arithmetic mean values, correlation analysis and regression analysis methods. According to the findings, it was found that there was a significant positive correlation between perceived organizational support levels and organizational identification levels of five-star hotel employees. A significant negative correlation was found between the perceived organizational support levels of the participants and intention to leave. Moreover, as a result of the simple linear regression analysis, it was determined that hotel employees' organizational support perceptions had a positively significant effect on organizational identification levels, and organizational support perception levels had a negative effect on their intention to leave.
\end{abstract}

Keywords: Perceived Organizational Support, Organizational Identification, Intention to Leave, Five Star Hotel Enterprises, Afyonkarahisar.

Received: 29.07.2019

Accepted: 06.10.2019

\section{Suggested Citation:}

Kılıç, G. and Gülen, M. (2019). The Effect of Perceived Organizational Support on Organizational Identification and Intention to Leave: The Case of Afyonkarahisar, Journal of Turkish Tourism Research, 3(4): 1570-1588.

(C) 2019 Türk Turizm Araştırmaları Dergisi. 


\section{Gíriş}

Turizm, günümüzde dünyada en önde gelen sektörler arasında yer almaktadır. Bununla birlikte, turizmin hizmet sektörü içerisinde yer alması nedeniyle istihdam açısından da ön plana çıkmaktadır. Bu bağlamda turizm işletmelerinde çalışanların örgüte gönüllü olarak katılımları ve yönetimin çalışanlara karşı tutum ve davranışları önem arz etmektedir. Bu doğrultuda işletmede çalışanların algılanan örgütsel destek algılarının örgütsel özdeşleşmeye nasıl bir etki yarattığı ve bu etkinin işletmenin çalışanları tarafından olumlu veya olumsuz olarak etkilediğinin ortaya konulması önemlidir. Bu etkinin olumsuz olması diğer bir deyişle çalışanın örgütte var olamaması işten ayrılma niyetini de kaçınılmaz kılmaktadır.

Bir çalışanın örgütsel özdeşleşme düzeyi, onun benliğinin örgüt üyeliğine ne derece bağlı olduğunu gösterir. Dolayısıyla, örgüt üyeliği bireyin benliğinde merkezli bir yer edinmişse ve onun diğer sosyal gruplardaki üyeliklerinden daha önemli bir konuma gelmişse, bu kişinin örgütte yüksek derecede özdeşleşmiş olduğu anlamına gelmektedir (Karabey ve İşçan, 2007: 232). Çalışanın duygusal bağlllık düzeyi, örgütsel hedefleri ve işletmeye karşı inancı (Tutar, 2013: 276) turizm işletmelerinde özellikle verimlilik konusunda insan kaynağının önemli olması; aynı zamanda turizm sektörünün emek-yoğun olması, insan ilişkilerinin olumlu olmasının gerekliliği sebebiyle dikkat çekmektedir.

Hizmet işletmelerinde, çalışan bir başarı faktörü olarak görülmektedir. Turizm sektöründe sunulan ürün (oda, yiyecek-içecek gibi) her ne kadar kaliteli olursa olsun müşterilerin bu ürünlerle ilk izlenimi önemli olmakla birlikte verilen hizmetin daha sağlıklı olması işletmede bulunan çalışanın verimli, istekli ve gönüllü çalışmasına bağlıdır. Bununla birlikte, yönetici tarafından çalışanın takdir görmesi örgütün bir üyesi olduğunu hissetmesi gerekmektedir. Dolayısıyla, işletmede zamanmaliyet unsurunun en aza indirilmesi de her iki taraf (çalışan-yönetici) açısında da yarar sağlamaktadır.

Çalışmada beş yıldızlı otel işletmesi çalışanlarının, örgütsel destek algıları ile örgütsel özdeşleşme düzeyleri ve işten ayrılma niyetleri arasındaki ilişki düzeyinin ortaya konulması amaçlanmaktadır. $\mathrm{Bu}$ çerçevede araştırma hem konu ile ilgili literatüre katkı sağlaması hem de otel işletmeleri yöneticilerine ve diğer paydaşlara veri kaynağı oluşturması açısından önemlidir. Ayrıca, ilgili literatür incelendiğinde konuya ilişkin yapılmış çalışmaların çok fazla olmaması nedeniyle araştırma önem taşımaktadır. Bununla birlikte, Afyonkarahisar'daki beş yıldızlı otel işletmeleri çalışanlarının algılanan örgütsel destek düzeylerini, örgütsel özdeşleşme düzeylerini ve işten ayrılma niyetlerinin belirlemesi önemlidir. Çünkü otel işletmeleri örgütsel destek algısı ve örgütsel özdeşleşme düzeyi yüksek olan işgörenler ile çalışmayı tercih etmektedirler. Bunun nedeni ise bu tür işgörenlerin motivasyonu, verimliliği ve performanslarının yüksek olabilmesinden dolayı daha kaliteli hizmet sunma imkanı sağlanmaktadır. Bununla birlikte, otel işletmelerinde müşteri memnuniyetinin artmasına da etki edebilmektedir. Aynı zamanda çalışanın örgütü tarafından destek görmesi veya bunu hissetmesi çalışanların daha kolay örgütü ile özdeşmesine de neden olabilmektedir. Dolayısıyla, emek yoğun bir sektör olan otel işletmelerinde çalışanların işletme tarafından değer verildiğini hissetmesi algılaması veya örgütü ile özdeşleşmesi işletmelerin amaçlarının tam uyumlu bir biçimde gerçekleştirilmesini de sağlayabilecektir.

\section{KAVRAMSAL ÇERÇEVE}

\section{Algılanan Örgütsel Destek}

Örgütler kuruluş amaçlarının yanında varlıklarını sürdürebilmek için girişimler yapmak, kararlar almak, araştırmalar yaparak bir düzen kurmak, kurulan düzeni geliştirmek ve en önemlisi o düzenin 
varlığını korumak için çalışmaktadır. Çalışanın örgüt adına göstermiş olduğu performansın, örgüt tarafından değerli bulunması ve bu değerin çalışana hissettiriliyor olması hem örgütlerin geleceği hem de çalışanların memnuniyeti açısından büyük önem arz etmektedir (Wang ve Netemeyer, 2002). Çalışanların örgüt tarafından desteklenmesi, çalışanların kendini önemli hissetmesine sebep olacağından, örgüt ile çalışan arasında olumlu yönde bir iletişime de neden olmaktadır. Örgütün, çalışanlarını bir değer kabul etmesi, mutluluklarını önemsemesi ve bunları çalışanlarına göstermesi, çalışanların örgüt ile olan duygusal ilişkilerini olumlu yönde etkilemektedir (Eisenberger vd., 1986).

Örgütsel destek bir örgütün, personelinin örgüte katkılarının bilincinde olması ve personelin refahına önem vermesi şeklinde ifade edilebilir. Örgütsel destek, ancak insan kaynaklarının öneminin bilincinde olan örgütlerde bulunabilecek özel bir anlayıştır. Bu anlayışa sahip olan örgütlerde insanların yaptıkları katkılar dikkate alındığı ve refah düzeyi artırıldığı için çalışan bu durumdan büyük gurur ve mutluluk duyar (Akın, 2008; Yılmaz ve Görmüş, 2012: 4488).

Algılanan örgütsel destek; örgütün işgörene, işgörenin de karşılığında örgüte gösterdiği bağlllı̆̆ın değiş-tokuşunda, örgüte düşen payın, işgören tarafından algılanış biçimidir (Güney vd., 2007: 195). Diğer yandan bir başka tanımda da çalışanın faaliyetleri sonucunda örgütüne yapmış olduğu katkının, çalıştığı örgüt tarafından bir değer olarak kabul edilmesinin ve örgütün çalışanın iyiliğiyle ilgilenmesinin, çalışan tarafından algılanması olarak tanımlanmaktadır (Hellman vd., 2006: 631). Diğer bir ifadeyle, işgörenlerin örgütleri tarafından ne kadar düşünüldüğü, örgütün işgörenin katkılarına ne kadar değer verdiği anlamına gelmektedir (Allen vd, 2008: 556). Çalışanlarının mutluluğunu ve esenliğini dikkate alan ve çalışanlarını destekleyen bir örgütte veya yönetimde bulunması gerekli özellikler beş (5)'e ayrılmaktadır. Bu özellikler şu şekildedir (Özdevecioğlu, 2003: 117-118):

- Çalışanların yaratıcı fikirlerini, önerilerini ve eleştirilerini dikkate almak ve bu önerileri uygulamaya aktarmak,

- Çalışanlara iş güvenliği sağlamak ve başarılı oldukları taktirde işyerinde devamlı çalışacaklarına ilişkin güvence vermek,

- Örgüt içindeki insan ilişkilerinin pozitif olmasını sağlamak, örgüt içi iletişimi ve hakla ilişkiler çalışmalarını yüksek seviyelerde tutmak,

- Örgüt içinde, adam kayırmacilık yapmamak, herkese adaletli davranmak, hak yememek,

- Çalışanları önemsemek ve onlara rağmen bazı kararları almamak şeklinde sıralanabilir.

Örgütsel destek algısını oluşturan faktörlerin neler olduğunun tespit edilmesine yönelik literatürde birçok araştırma yapılmıştır. Rhoades ve Eisenberger'a (2002) göre, örgütsel destek algısını oluşturan faktörler; örgütsel adalet, çalışma koşulları, amir desteği ve örgütün çalışanların gelişimi için sunduğu fırsatlardır. Yapılan başka çalışmalarda belirtilenlere ek olarak insan kaynakları yönetimi uygulamaları ve kişilik özellikleri gibi faktörlerin de etkili olabileceği vurgulanmıştır (Yüksel, 2006).

İşletmeler rekabet avantajı elde ederken çalışanların örgüte katılmalarına da katkı sağlamak durumundadırlar. Bu doğrultuda, Tüzün ve Kalemci'nin (2012) yaptıkları çalışmaya göre, çalışan bireylerin yönetici desteğinin olması buna karşılık örgüt desteğinin olmaması onları işten ayrılma niyetine itmektedir. Bu da örgütsel desteğin çok önemli olduğunu vurgulamaktadır (Tüzün ve Kalemci, 2012: 518-534).

Algılanan örgütsel desteğin sonuçlarından biri olan devamsızlıkta en dikkat çeken Rhoades ve Eisenberger (2002) tarafından yapılan çalışmada işe geç gelme, işe gelmeme, işten ayrılma veya iş arama gibi farklı yollara yönelme gibi durumların algılanan örgütsel desteği olumsuz yönde etkilediği vurgulanmaktadır (Giray, 2013).

Algılanan örgütsel destek, sosyal değişim kuramı içerisinde de yer almakta ve kurama göre çalışanlar, örgütlerinden destek gördüklerinde bunu örgütlerine olumlu tutum ve davranışlar olarak 
yansıtmaktadırlar (Uzun, 2018: 133). Turizm işletmeleri açısından diğer işletmelere göre bu durum daha çok ön plana çıkmaktadır. Turizm işletmelerinde müşteri ilişkileri göz önüne alındığında çalışanın bulunduğu ortamda desteklenmesi müşteriye verilecek olan izlenimi de göstermektedir.

Boz vd., (2017) yaptıkları çalışmada, otel işletmeleri temelinde algılanan örgütsel desteğin algılanan örgütsel bağlllık üzerindeki etkisini ortaya koymuştur. Bulgular sonucunda, otelde çalışan bireylerin örgütsel destek algıları arttıkça işe olan devamlılıkları ve bağlılıkları arttığını, ancak genel bağlılık düzeylerinin ise azaldığı sonucuna ulaşmışlardır.

Kaplan ve Öğüt (2012) çalışmalarında, Nevşehir ilinde faaliyet gösteren 4 ve 5 yıldızlı otel işletmelerinde çalışan işgörenlerin örgütsel destek algılamaları ile örgütsel bağlılıkları arasındaki ilişkiyi irdelemeyi amaçlayan araştırma sonucunda; algılanan örgütsel destek ile duygusal ve normatif bağlılık arasında pozitif yönlü bir ilişki izlenirken, algılanan örgütsel destek ile devam bağlılığı arasında negatif yönlü bir ilişki bulunduğu sonucuna ulaşmışlardır.

Turunç ve Çelik (2010) yaptıkları çalışmalarında, küçük ölçekli işletmelerde çalışanların algılanan örgütsel desteğin iş performansı ve iş stresinin özdeşleşme üzerindeki etkisini ölçmüşlerdir. Bulgularda ise, iş stresinin ve algılanan örgütsel desteğin örgütsel özdeşleşmeyi etkilediği, örgütsel özdeşleşmenin iş performansına ve iş stresiyle iş performansı arasındaki aracılığınıda pozitif etki ettiği sonucuna ulaşmışlardır.

Bal (2018) ise çalışmasında algılanan örgütsel destek, örgüte uyum ve hizmet performansı arasında orta-yüksek düzeyde ilişki bulunduğunu ve örgütsel destek ile örgüte uyum düzeylerinin, algılanan hizmet performansı üzerinde anlamlı bir etkisi olduğunu tespit etmiştir. Dolayısıyla, algılanan örgütsel destek algısının çalışanlarda olumlu düzeyde olması durumunda verimliliğin, iş performansının artacağı örgütsel bağlllıklarının ve örgütsel özdeşleşme düzeylerinin de yükseleceği söylenebilir.

\section{Örgütsel Özdeşleşme}

Örgütsel özdeşleşme bireyin sosyal kimliğinin bir parçası ve örgütsel kimliğinin bir çıktısı olarak ifade edilmektedir. Diğer bir deyişle, bireyin kendini tanımlamak için örgütün kimliğini kullanarak bu tanımlamayı gerçekleştirmesidir (Aliyev ve Işık, 2014: 139). Örgütsel özdeşleşme, başarı ve başarısızlık durumlarını da içerisinde yer alan, aidiyet, birlik olma algıları, bireyin kendini tanımlarken de örgütle beraber tanımlaması, düşünce bağlamında örgütü kendine ait bir parça olarak hissetmesi durumlarıdır (Turunç ve Çelik, 2010: 213). Başka tanımda ise, bireylerin kendilerini örgütle bütünleştiren kişisel ilişkilerini tanımlaması anlamına gelir. Böylece örgütsel özdeşleşme, bireyler ile örgüt arasında psikolojik bir bağ olarak ortaya çıkmaktadır (Wiesenfeld vd., 1999: 778).

Örgütsel özdeşleşme, örgütün değerleri ile örgütün üyelerinin bütünleşmesi ve uyum içerisinde hareket etmesi süreci olarak tanımlanabilir. Bu durum, bireyin özellikleri ile örgütün özelliklerinin psikolojik anlamda bağlllık içerisinde olmasını ifade etmektedir (Katrinli vd., 2008: 356). Örgütsel özdeşleşme, çalışanlar ile örgüt arasında var olan ilişkiyi ve bu ilişkinin niteliğini yansıtan anahtar unsurlardan birisidir. Böylece, çalışanların iş yaşamlarındaki tutum ve davranışlarının öngörülebilmesinin ve açıklanmasının da temelini oluşturmaktadır. Örgütsel özdeşleşme, çalışanların motive edilebilmesi ve örgütsel performansın arttırılabilmesi için gerekli olan psikolojik ilişkinin gelişmesini sağlayan, örgütlerin yararına olan bir anlayış olarak vurgulanmaktadır (Cheung ve Law, 2008: 213).

Örgütsel Özdeşleşme türleri Kimliksizleşme, Nötr özdeşleşme, Kararsız özdeşleşme ve Çift yönlü özdeşleşme olarak sınıflandırılmaktadır. 
Kimliksizleşme: Kimliksizleşme, bir bireyin kimliği ile bu bireyin içerisinde bulunduğu örgütün kimliği üzerindeki algısı arasındaki bilişsel ayrılığa dayanarak oluşturduğu kişisel bir algı ve bireyin kendisi ile örgütü arasındaki negatif yönlü ilişkisel sınıflandırmasıdır (Bhattacharya ve Elsbach, 2002: 28).

Nötr Özdeşleşme: Nötr özdeşleşme; bir işgörenin kendisini örgütün bütünü, amaçları, hedefleri ile misyonuna karşı nötr olarak tanımladığı ve ek rol davranışları yoluyla örgüte katkıda bulunan diğer işgörenlere göre daha az müdahil hissettiği, standartların altında kalan bir durum olarak düşünülmektedir (Kreiner ve Ashforth, 2004: 5).

Kararsız Özdeşleşme: Kişinin aynı anda örgütüyle hem özdeşleşip hem de özdeşleşmemesi kararsız özdeşleşme olarak ifade edilmektedir. Birey örgütün belli bir özelliğini benimseyerek, belli bir yönü ile özdeşleşirken; belli özelliklerini benimsemeyerek, belirli yönleri ile de özdeşleşmeyebilir. Bu durumdaki çalışanlar, örgüt amaçları doğrultusunda çabalamakta ancak performanslarını gerektiğinden fazla artırma konusunda isteksiz olmaktadırlar (Kreiner ve Ashforth, 2004: 4).

Çift Yönlü Özdeşleşme: Bazı durumlarda örgüt üyeleri aynı anda, birbirleri ile uyumlu ya da uyumsuz çok sayıda özdeşleşme yaşayabilmektedirler. 'Çifte özdeşleşme fenomeni' olaraktan bilinen bu olgu, işgörenin birden fazla örgüt ile kendi örgütü ve bağlı bulunduğu sendikası ve özdeşleşmesi sonucunda oluşmaktadır. Ayrıca işgörenler, yakın iş arkadaşları veya meslekleri ile örgütün bütünü ile olduklarından daha çok özdeşleşebilmektedirler (Immordino, 2010: 141). Bu yüzden özdeşleşme, sadece bir yönetim stratejisi olarak düşünülmemelidir (Boessenkool vd., 2003: 31).

Algilanan Örgütsel Kimlik, örgüt üyesinin örgütün kimliğinin ne olduğuna ya da örgütün farklı, merkezi ve devamlı olarak tanımlanan özelliklerine ilişkin inancıdır (Dutton vd., 1994: 244). Algılanan örgütsel kimliğin tanımlanmasında kullanılan özellikler büyük ölçüde, kişinin diğer üyelerle olan etkileşimleri, kişiler arası ilişkileri, resmi ya da resmi olmayan iletişimleri ve örgüt imajını da içeren çevreden aldığı bilgilerden oluşmaktadır. Üyelerin sıklıkla diğer üyelerle etkileşim içinde bulunması ve örgüt hakkında daha sık bilgiler edinmesi yoluyla örgütün merkezi, belirgin, devamlı ve farklı özelliklerinin sürekli akılda kalacağı ve örgütle özdeşleşme derecelerinin artacağı düşünülmektedir (Ekmekci ve Casey, 2009: 52).

Örgütsel Destek, işgörenlerin saygı ve duygusal açıdan yakınlık ihtiyaçlarını karşılamasından dolayı bilinen algılanan örgütsel destek, örgütsel özdeşleşmede gelişim sağlamaktadır (Gibney vd., 2011: 1089). Turizm işletmelerinin hizmet sektörü olması nedeniyle işletme içerisinde çalışanların tutumları ve davranışları örgütte var olmasını sağlamaktadır. Dolayısıyla örgütsel özdeşleşme ile ilgili yapılan çalışmalar bunu kanıtlar niteliktedir.

Solnet (2006) Avustralya'da otel işletmesinde yapmış olduğu çalışmada; müşteri odaklı örgütsel uygulamalar ile yakın ilişkili olan hizmet iklimi unsurlarının, müşterinin memnun kılınması ve üst kademe işgören özdeşleşmesinin önemli belirleyicileri etkenler olduğunu vurgulamıştır. Tuna ve Yeşiltaş (2014) tarafından yapılan çalışmada ise; Ankara ve Antalya illerinde bulunan beş yıldızlı otel işletmelerindeki çalışanlarda, etik iklim türleri olan kişisel ahlak ve kişisel çıkarın yabancılaşma üzerinde, kişisel çıkarın örgütsel özdeşleşme üzerinde etkisi olduğu belirtilmiştir.

Akşit Aşık (2017) çalışmasında Balıkesir'de faaliyet gösteren otel işletmeleri çalışanlarının otonomik kişilik özelliğinin alt boyutu olan kişisel başarının örgütsel özdeşleşmeyi pozitif yönde etkilediğini; ayrıca sosyotropik kişilik özelliğinin alt boyutlarından ayrılık kaygısının örgütsel özdeşleşmeyi negatif yönde etkilediğini ifade etmiştir.

Yeşiltaş (2012) çalışmasında etik liderlik ve etik iklimin alt boyutları ile örgütsel özdeşleşme arasında pozitif yönlü ve anlamlı bir ilişkinin olduğu sonucuna varmıştır. Yarmacı (2012) tarafından otel işletmeleri çalışanlarının psikolojik güçlendirme algılarının örgütsel özdeşleşme üzerine etkisini 
belirlemeye yönelik yaptığı araştırmasında çalışanların psikolojik güçlendirme algıları ile örgütsel özdeşleşme seviyeleri arasında pozitif yönlü orta düzeyde bir ilişki olduğu belirtilmiştir.

Bununla birlikte örgütü ile özdeşleşen işgören işletme için olumlu davranışlar gösterebilecektir. Dolayısıyla, işgören örgütsel özdeşleşme davranışını algılanan örgütsel destek düzeyleri olumlu algılandığında gösterebilecektir. Buna karşılık algılanan örgütsel desteğin olumsuz olması durumunda da işe devamsızlık, işten ayrılma niyeti gibi işletmeler tarafından istenmeyen negatif durumlara da neden olabilecektir.

\section{İşten Ayrılma Niyeti}

İnsan kaynakları yönetiminde, personelin örgütte kalması örgütsel performans göstergelerinden birisidir. Bu nedenle yöneticiler bünyelerinde etkili ve verimli çalışan bireyleri örgütlerine bağlamak için çalışırlar (Çekmecelioğlu, 2006). Bu doğrultuda, işten ayrılma niyeti tanımı şu şekilde ifade edilebilir. İşörenlerin işte kalma veya işten ayrılma gibi kararların belirleyen bir unsur olduğu ve işgörenin davranış olarak henüz eyleme dönüştürmediği olumsuz bir niyet olduğu şeklinde ifade edilebilir (Özdevecioğlu, 2004: 99).

İşten ayrılma niyeti, işgörenlerin örgütlerinde memnuniyetsizlik duymaları ve işten ayrılmayı düşünmeleri durumudur (Yıldırım vd., 2014: 36). Öte yandan yazarlar işten ayrılma niyetini, 'iş şartlarından tatmin olmayan işgörenlerin içine girmiş oldukları aktif ve yıkıcı eylem olarak' ifade ederken (Onay ve Kılcı, 2011: 365); bir başka tanımda da 'bir işgörenin yakın bir zamanda kendi isteğiyle ve bazı nedenlerin etkisiyle işine son verme düşüncesi' olarak tanımlanmaktadır (Yıldız vd., 2014: 236).

İşten ayrılma niyeti, çalışma yaşamında pek çok faktörlerden etkilenebilen hassas bir konudur (Turunç ve Avc1, 2015: 58). Özellikle emek-yoğun bir sektör içerisinde yer alan turizm işletmelerinde bu durum diğer sektörlere göre daha fazladır.

İşten ayrılma eğiliminin işletmeler, genel ekonomi ve işgörenler açısından önemli sonuçları bulunmaktadır. Konaklama işletmeleri için yeni işgören bulma, eğitme, uyum sağlama, iş kazaları gibi maliyetleri olmaktayken, genel ekonomiye de iş kaybı, üretim kaybı olarak yansımaktadır. İsgörenler açısından da, gelirinde düzensizlik, psikolojik sorunlar, ailevi sorunlar, işe özel kazanımların boşa gitmesi, yeni işe uyum, yeni eğitim gibi maliyetleri bulunmaktadır (Avcı ve Küçükusta, 2009: 37). İşten ayrılma niyetini etkileyen unsurlara bakıldığında, işletmeler işgörenlerin işten ayrılmasına ilişkin durumları önceden tahmin edilebilmekte, açıklamakta ve gerekli önlemler alabilmektedir. İşgörenler; iş atmosferi, iklimi, çalışma arkadaşları ile ilişkiler, kurumdan talep ve beklentileri ile kariyer geliştirme ve otonomi gibi durumlardan etkilenerek işten ayrılma düşüncesi içerisine girmektedirler (İşçi, 2010).

Aşırı iş yükü ve iş stresi, rol belirsizliği ve rol çatışması, açık olmayan iş tanımları, olumsuz çalışma koşulları, düşük ücret, kısıtlı terfi olanakları, bireyler arası yıpratıcı ilişkiler, sosyal destekten yoksunluk, çalışma ortamındaki iletişim sorunları ve çatışmalar, yönetimin uygulamalarından duyulan memnuniyetsizlik, örgütteki eşitsizlik ve adaletsizlik algısı gibi faktörler, işten ayrılma niyetinin ve dolayısıyla işgören devrinin güçlü belirleyicileri arasında yer almaktadır (Sabuncuoğlu, 2007).

İse devam eden veya işten ayrılma niyeti olan, memnun olmadan çalışmak zorunda kalan işgören, iş düzenini bozucu ve çatışma yaratan davranışlar göstermeye başlayabilir (Akoğlan Kozak, 2012: 88). Turizm sektöründe, işgören diğer üretim faktörlerine oranla daha da önem kazanmakta ve bir konaklama işletmesinin başarısı ve varlığını koruyabilmesi müşteri memnuniyetiyle mümkün olabilmekte, bunu sağlayan da işgörenlerin sunduğu kaliteli hizmetle gerçekleşme ile 
sağlanmaktadır. Konaklama işletmesinde, insan kaynaklarının nitelikli işgörenin seçilmesi, kazandırılması kadar o işgörenin işletmede tutulması işlevi de bulunduğundan önemlidir (Avcı ve Küçükusta, 2009: 36).

\section{Algılanan Örgütsel Destek, Örgütsel Özdeşleşme ve İşten Ayrılma Niyeti Arasındaki İlişki}

Konuyla ilgili literatür incelendiğinde; algılanan örgütsel destek, örgütsel özdeşleşme ve işten ayrılma niyeti arasında önemli ilişkiler bulunmaktadır. İşgörenler örgütlerinden olumlu yönde örgütsel destek algıladıkça işten ayrılma niyetleri azalmaktadır (Edwards ve Peccei, 2010; Ekmekçioğlu ve Sökmen, 2016). Bu durum çalışanın örgütte değer gördüğü ve işletmede alt-üst ilişkilerinde iletişimin güven üzerine olup beklentilerin karşılandığını gösterir niteliktedir.

Polat (2009) örgütsel özdeşleşme konusu üzerine yapmış olduğu çalışmasında, örgütsel özdeşleşmenin örgütsel nitelikteki öncüllerini; örgütsel adalet algısı, örgütsel bağlılık, iş yaşamında özerklik, meslekle özdeşleşme, lider-liderlik, imaj ve örgütün farklılığına ilişkin algı, kariyer gelişimi ve başarı fırsatı, grup içinde saygı görme, grubun büyüklüğü, sosyalizasyon taktikleri, proaktif davranışlar ve yeni gelenlerin öğrenimleri, iletişim, algılanan örgütsel kimliğin çekiciliği, örgütsel güven, örgüt içi rekabet, örgütsel sinizm gibi birçok faktörler olduğunu ifade etmiştir. Yazarın örgütsel özdeşleşme ile ilgili bahsettiği ifadeler diğer işletmelerde olduğu gibi hizmet sektöründe yer alan turizm işletmelerinde de müşteri memnuniyeti ön plana alındığından kavramların birbiriyle olan ilişkileri yadsınamayacak kadar büyük önem arz etmektedir.

Algılanan örgütsel destek ile işten ayrılma niyeti arasındaki ilişkiyi araştıran diğer bir çalışma Dawley vd., (2010) tarafından yapılan çalışmadır. Bu çalışma sonuçları diğer çalışmalarda olduğu gibi bu iki kavram arasında negatif yönlü bir ilişki olduğu yönündedir (Koçak ve Yücel, 2018: 687). Akyüz vd. (2015) çalışmasında da işgörenlerin işten ayrılma niyetini etkileyen faktörler olarak örgütsel özdeşleşme ve örgütsel iletişimin konaklama işletmelerinde işten ayrılma niyeti üzerindeki etkisini araştırmışlardır. Araştırma sonucunda örgütsel özdeşleşme ile işten ayrılma niyeti arasında negatif bir ilişki olduğunu tespit etmişlerdir. Bütün bu elde edilen bulgular neticesinde algılanan örgütsel destek ile işten ayrılma niyeti arasında negatif bir ilişki olduğu dolayısıyla işgörenlerin algılanan örgütsel desteği olumsuz algılamaları sonucunda işten ayrılma niyetlerinin de arttığı ifade edilebilir. Buna karşılık örgütsel desteğin olumlu algılanması sonucunda daörgütsel bağlılığın, örgütsel özdeşleşme düzeylerini de olumlu yönde etkilediği görülmüştür.

\section{Çalışmanın Amacı ve Önemi}

Bu araştırmada algilanan örgütsel desteğin örgütsel özdeşleşme ve işten ayrilma niyetine etkisini belirlemek amaçlanmıştır. İlk olarak algılanan örgütsel destek, örgütsel özdeşleşme ve işten ayrılma niyetine ilişkin literatür taraması yapılarak teorik bilgilere yer verilmiştir. Bununla birlikte, Afyonkarahisar'da faaliyet gösteren beş yıldızlı otel işletmeleri çalışanları üzerinde uygulama yapılarak ortaya konulmaya çalışılmıştır.

\section{Araştırmanın Hipotezleri}

Algılanan örgütsel destek ile örgütsel özdeşleşme arasındaki ilişkiyi tespit etmeye yönelik ilgili literatür incelendiğinde çok fazla çalışmaya rastlanmamıştır. Özdevecioğlu (2003) algılanan örgütsel destek ile örgütsel bağlılık arasındaki ilişkinin belirlenmesine yönelik yaptığı çalı̧̧mada algılanan örgütsel destek ile normatif bağlılık arasında pozitif ve anlamlı bir ilişki, duygusal bağlılık ile 
arasında pozitif ve anlamlı bir ilişki, devamlılık bağlılığı ile arasında ise pozitif yönlü ve anlamlı bir ilişki olduğunu aktarmıştır. Turunç ve Çelik (2010) tarafından işgörenlerin algıladıkları örgütsel desteğin örgütsel özdeşleşme üzerine etkisini belirlemek için yaptıkları araştırma sonucunda algılanan örgütsel desteğin örgütsel özdeşleşme düzeylerini pozitif ve anlamlı olarak etkilediği belirtilmiştir. Sökmen vd. (2015) tarafından yapılan araştırmada, algılanan örgütsel destek değişkeni ile örgütsel özdeşleşme arasında pozitif yönlü ve anlamlı bir etkisi olduğu tespit edilmiştir.

İlgili literatür incelendiğinde genel olarak elde edilen değerlere göre algilanan örgütsel desteğin örgütsel özdeşleşme üzerine etkisini belirlemek amacıyla oluşturulan hipotez şu şekildedir.

H1: “Beş yıldızlı otel işletmesi çalışanlarının örgütsel destek algıları ile örgütsel özdeşleşme düzeyleri arasında pozitif yönlü ve anlamlı bir ilişkisi vardır." şeklinde kurulmuştur.

Diğer taraftan algılanan örgütsel destek ile işten ayrılma niyeti arasındaki ilişkiyi tespit etmek amacıyla yapılan araştırmada şu bulgular tespit edilmiştir.

Anafarta (2015) tarafından yapılan çalışmada algılanan örgütsel destek ile işten ayrılma niyeti arasında orta derecede negatif ve anlamlı bir ilişki bulunmuştur. Koçak ve Yücel (2018) yaptıkları araştırma sonucunda algılanan örgütsel destek ile işten ayrılma niyeti arasında negatif yönlü ve istatistiksel olarak anlamlı bir ilişki elde etmişlerdir. Bağdoğan (2018) bankacılık sektörü çalışanları üzerine yaptığı çalışmasında algılanan örgütsel destek ile işten ayrılma niyeti arasında negatif ve anlamlı bir ilişki tespit etmiştir.

Buna göre, ilgili literatür incelendiğinde elde edilen genel bulgulara göre algılanan örgütsel desteğin işten ayrılma niyeti üzerine etkisini belirlemek amacıyla oluşturulan hipotez şu şekildedir.

$\mathbf{H}_{2}$ : "Beş yıldızlı otel işletmesi çalışanlarının örgütsel destek algıları ile işten ayrılma niyetleri arasında negatif yönlü ve anlamlı bir ilişkisi vardır." şeklinde kurulmuştur.

\section{YÖNTEM}

\section{Evren ve Örneklem}

Araştırmanın evrenini Afyonkarahisar'da faaliyet gösteren beş yıldızlı otel işletmeleri çalışanları oluşturmaktadır. Araştırmada evrenin tamamı yerine zaman, maliyet gibi unsurlar nedeniyle örneklem alma yoluna gidilmiştir. Evreni temsil düzeyine sahip örneklem seçiminde olasılık dışı örneklem yönteminden kolayda örnekleme yöntemi kullanılmıştır.

Kültür ve Turizm Bakanlığı'nın 2007 yılı verilerine göre, Türkiye' de beş yıldızlı bir otel işletmesinde oda başına düşen çalışan sayısı 1.18'dir (Pelit, 2008: 130). Afyonkarahisar İl Kültür ve Turizm Müdürlüğü (2018) verilerine göre Afyonkarahisar ilinde Ömer-Gecek bölgesinde 7 adet, Hüdai termal bölgesinde ise 3 adet faaliyet gösteren beş yıldızlı otel işletmesi bulunmaktadır ve bu otellerde toplam 2986 oda yer almaktadır (www.afyonkulturturizm.gov.tr). Bu verilere göre toplam yatak sayısı ile yatak başına düşen personel sayısı çarpıldığında, 2986*1,18 = 3523 sonucu elde edilir. Bu rakam bu araştırmada kullanılan formüller çerçevesinde evrenin sınırsız $\mathrm{N}<10.000$ 'den küçük olduğunu (sınırlı evren) ortaya koymaktadır. Nicel araştırmalar için önerilen örnekleme hacmi hesaplama formülünden yararlanılarak (Ural ve Kılıç, 2011: 47) örneklem sayısı 346 kişi olarak tespit edilmiştir.

Afyon Kocatepe Üniversitesi'nin Bilimsel Proje Araştırmaları Koordinasyon Birimi'nce (BAPK) desteklenen bu araştırmada hedeflenen örneklem sayına ulaşılması için Afyonkarahir ilindeki beş yıldızlı otel işletmelerine 550 adet anket dağıtılarak BAPK projesi dahilinde 2018 yılının Eylül ve Ekim ayları arasında uygulanmıştır. Geriye dönen anket sayısı 450 adet olup, eksik ve hatalı 
doldurulması gibi sebeplerden dolayı 43 adet anket değerlendirilmeden çıkarılmıştır. Dolayısıyla toplam 407 adet anket analiz işlemine dâhil edilmiştir.

\section{Veri Toplama Yöntemi}

Uygulamalı bir nitelik taşıyan bu araştırmada veri toplamak amacıyla anket tekniği kullanılmıştır. Bu çerçevede algılanan örgütsel destek, örgütsel özdeşleşme ve işten ayrılma niyeti ile ilgili literatür taraması yapılmış ve beş yıldızlı otel işletmeleri çalışanlarının örgütsel destek algıları ile örgütsel özdeşleşme ve işten ayrılma niyetine etkisini belirlemek amacıyla uygulanan anket formu dört bölümden oluşmaktadır. Birinci bölümde çalışanların bireysel özellikleri ve işletmeye ait özelliklerinin yer aldığı 10 adet kapalı uçlu soru bulunmaktadır. İkinci bölümde beş yıldızlı otel işletmeleri çalışanlarının algılanan örgütsel destek düzeylerini belirlemek amacıyla Eisenberger ve diğerleri (1986: 502) tarafından geliştirilen 36 ifadeden oluşan daha sonra Rhoades ve Eisenberger (2002: 699) tarafından revize edilerek tek boyut ve 8 maddelik kısa haline dönüştürülen ölçek, Yılmaz (2016) ve Kaya (2012)'nın çalışmalarında yer alan Türkçe'ye çevrilmiş hali ile kullanılmıştır. Anketin üçüncü bölümünde ise örgütsel özdeşleşme düzeyini belirlemek amacıyla araştırmalarda yaygın olarak kullanılan, Meal ve Ashforth (1992) tarafından geliştirilen ve Yarmacı (2012) tarafından Türkçe'ye çevrilen ölçek kullanılmıştır. Örgütsel özdeşleşme ölçeği tek boyuttan ve 6 ifadeden oluşmaktadır. Anketin son bölümünde ise beş yıldızlı otel işletmeleri çalışanlarının işten ayrılma niyetini belirlemek amacıyla Cammann ve diğerleri (1979) tarafından geliştirilen ve Gülertekin (2013) tarafından Türkçe'ye çevrilerek çalışmasında kullanılan tek boyut ve üç ifadeden oluşan işten ayrılma niyeti ölçeği kullanılmıştır. Her üç ölçeğe ilişkin katılım derecelerini belirlemek amacıyla ise "1=Hiç Katılmıorum" ve “5=Tamamen Katılıyorum" şeklinde derecelendirilmiştir.

\section{Verilerin Analizi Yöntemi}

Beş yıldızlı otel işletmeleri çalışanlarının örgütsel destek algılarının örgütsel özdeşleşme düzeylerine ve işten ayrılma niyetlerine etkisini belirlemek amacıyla yapılan bu araştırmada elde edilen veriler sosyal bilimler için kullanılan istatistiksel paket programı ile analiz edilmiştir. Afyonkarahisar da faaliyet gösteren beş yıldızlı otel işletmelerinde araştırmaya katılan çalışanlarının bireysel özellikleri ve işletmeye ait özelliklerine ilişkin yüzde ve frekans dağılımları verilmiştir. Bununla birlikte, algılanan örgütsel destek ve örgütsel özdeşleşme ve algılanan örgütsel destek ve işten ayrılma niyeti arasındaki ilişki Pearson korelasyon katsayısı ile belirlenmiştir.

Beş yıldızlı otel işletmeleri çalışanlarının örgütsel destek algılarının örgütsel özdeşleşmeye etkisini belirlemek ve yine çalışanların örgütsel destek algısının işten ayrılma niyetlerine etkisini tespit etmek amacıyla basit doğrusal regresyon analizi uygulanmıştır. Ayrıca, araştırmada kullanılan algılanan örgütsel destek, örgütsel özdeşleşme ve işten ayrılma niyetine ilişkin yer alan ölçeklerin geçerliliğini ve güvenirliğini tespit etmek amacıyla analizler uygulanmıştır. Bu çerçevede geçerliliğini tespit etmek amacıyla açıklayıcı faktör analizi, güvenirliğini belirlemek amacıyla ise Cronbach's Alpha değeri hesaplanarak sunulmuştur.

\section{BULGULAR ve TARTIŞMA}

Anket formunda yer alan tüm ölçeklere ilişkin güvenirlik analizi yapılmıştır. Buna göre, bütün ölçeklerin güvenirlik katsayısının 0,80'nin üzerinde olduğu tespit edilmiştir. Bununla birlikte araştırma kapsamında kullanılan ölçeklerin geçerliliğini belirlemek amacıyla açıklayıcı faktör analizi yapılmıştır. Tablo 1'de algılanan örgütsel destek ölçeğine ilişkin yapılan güvenirlik analizi ve faktör analizinin sonuçları verilmiştir. 
Algılanan örgütsel destek ölçeğine ilişkin yapılan güvenirlik analizi sonucunda cronbach's alpha değeri 0,81 olarak örgütsel özdeşleşme ölçeğine ilişkin yapılan güvenirlik analizi sonucunda cronbach's alpha değeri 0,89 olarak işten ayrılma niyeti ölçeğine ilişkin yapılan güvenirlik analizi sonucunda ise cronbach's alpha değeri 0,92 olarak hesaplanmıştır. Bu durumda güvenirlik katsayısı 0 ile 1 arasında değerler alır ve bu değer 1'e yaklaştıkça güvenirlik düzeyinin yüksek olduğu anlamını taşır (Ural ve Kılıç, 2011: 286). Buna göre algılanan örgütsel destek ölçeğine ilişkin güvenirlik katsayısının oldukça güvenilir olduğu söylenebilir.

Algilan örgütsel destek ölçeğine ilişkin örneklem yeterlilik testinin sonucu olan Kaiser- Meyer-Olkin (KMO) değeri 0,810 ve faktör analizi yapılmasının uygunluğunu ölçen Bartlett Küresellik testinin sonucu $(X 2=1259,253$; p <0,001) anlamlı bulunmuştur. Akgül ve Osman Çevik, (2003)'e göre KMO testi, dağılımın faktör analizi için yeterli olup olmadığını test etmektedir ve $0.80-0.90$ aralığı çok iyi olarak değerlendirilmektedir (Erdoğan, Bayram ve Deniz, 2007: 5). Dolayısıyla bu araştırmada da KMO değerinin çok iyi düzeyde olduğu söylenebilir. İlgili test sonuçları incelendiğinde algılanan örgütsel destek ölçeğine açıklayıcı faktör analizi yapılmasının uygun olacağı tespit edilmiştir. Uygulanan açıklayıcı faktör analizi sonucunda ölçekte yer alan 8 (sekiz) maddenin tek bir faktör altında toplandığı tespit edilmiştir. Tek bir faktör altında toplanan sekiz madde toplam varyansın \% 66,011'ini açıklamaktadır. Algılan örgütsel desteğe ilişkin faktör analizi sonucuna göre faktör yüklerinin 0,72 ile 0,850 arasında değişiklik gösterdiği tespit edilmiştir.

Tablo 1'de örgütsel özdeşleşme ölçeğine ilişkin KMO değeri 0,893 ve Bartlett Küresellik testi sonucu anlamlı olarak bulunmuştur $\left(x^{2}=1332,385 ; p<0,001\right)$. Yapılan açıklayıcı faktör analizi sonucunda bütün maddelerin ön koşulları sağladığı ve ölçekte bulunan 6 (altı) maddenin tek bir faktör altında toplandığ 1 tespit edilmiştir. Tek faktör altında toplanan altı madde toplam varyansın \%66,336'sını açılamaktadır. Örgütsel özdeşleşmeye ilişkin faktör analizi sonucuna göre faktör yüklerinin 0,72 ile 0,850 arasında değişiklik gösterdiği tespit edilmiştir. Araştırma kapsamında yer alan diğer bir ölçek olan işten ayrılma niyeti ölçeğinde ilk iki ölçekte belirlenen ön koşullar ele alınarak açıklayıcı faktör analizi uygulanmıştır. Ölçeğin açıklayıcı faktör analizine uygunluğunu tespit etmek için KMO ve Bartlett Küresellik testi sonuçlarına bakılmıştır. Buna göre, ölçeğin KMO değeri 0,713 ve Bartlett Küresellik testi sonucunun anlamlı $\left(\mathrm{x}^{2}=1025,921 ; \mathrm{p}<0,001\right)$ olmasından dolayı açıklayıcı faktör analizi yapılmasının uygun olduğu söylenebilir. Ölçekte yer alan üç maddenin tek faktör altında toplandığı ve varyansın \%87,38'ini açıkladığı görülmüştür. İşten ayrılma niyeti ölçeğine ilişkin uygulanan faktör analizi sonucuna göre faktör yüklerinin 0,920 ile 0,963 arasında değişiklik gösterdiği tespit edilmiştir.

Araştırmaya katılan beş yıldızlı otel işletmesi çalışanlarının bireysel özellikleri ve işletmeye ait özelliklerine ilişkin bulgular incelendiğinde katılımcıların, \%53'e yakını erkektir. Çoğunluğunun, $(\% 90,9)$ otelde daimi olarak çalıştığı, $(\% 57,5)$ evli olduğu ve $(\% 50,4)$ turizm eğitimi almadığı saptanmıştır. Bununla birlikte, otel çalışanlarının \%50'e yakını 2 ve 4 yıl aralığında bulundukları otelde, \%33'ünün ise turizm sektöründe çalıştıkları tespit edilmiştir. Ayrıca, en çok katılımcının (\%28,5) 27- 32 yaş aralığında olduğu belirlenmiştir. Diğer taraftan, katılımcların yaklaşık \% 35'inin ortaöğretim düzeyinde eğitim aldığı ve $2010 \mathrm{Tl}$ ve altında aylık gelire sahip oldukları görülmüştür. Çalıştıkları departmanlar incelendiğinde ise \%25,3'ünün SPA bölümünde, \%18,9'unun Kat hizmetlerinde, $\% 17,7^{\prime} \operatorname{sinin}$ Yiyecek- içecek bölümünde ve \%15'inin ise Önbüro da çalıştığ belirlenmiştir. 
Tablo 1. Algılanan Örgütsel Destek Ölçeğine Ait Faktör ve Güvenirlilik Analizleri

\begin{tabular}{|c|c|c|c|c|}
\hline Faktör ve İfadeler & $\begin{array}{c}\text { Faktör } \\
\text { Yükü }\end{array}$ & Özdeğer & $\begin{array}{c}\text { Varyans } \\
(\%)\end{array}$ & $\begin{array}{c}\text { Cronbach's } \\
\text { Alpha }\end{array}$ \\
\hline Faktör 1: Algılanan Örgütsel Destek & & 3,881 & 66,011 & 0,818 \\
\hline $\begin{array}{l}\text { Çalıştığım otel, otelin iyiliğine yönelik yaptığım katkılara } \\
\text { değer verir. }\end{array}$ & 0,725 & & & \\
\hline Çalıştığım otel, gösterdiğim ekstra çabayı takdir etmez. & 0,771 & & & \\
\hline Çalıştığım otel, şikayetlerimi dikkate almaz. & 0,843 & & & \\
\hline Çalıştığım otel, gerçekten iyiliğimi düşünür. & 0,805 & & & \\
\hline $\begin{array}{l}\text { Çalıştığım otel, işimi mümkün olan en iyi şekilde yapsam } \\
\text { bile bunu fark etmez. }\end{array}$ & 0,806 & & & \\
\hline $\begin{array}{l}\text { Çalıştığım otel, genel olarak işimle ilgili memnuniyetimi } \\
\text { önemser. }\end{array}$ & 0,826 & & & \\
\hline Çalıştığım otel, bana çok az yakınlık gösterir. & 0,731 & & & \\
\hline Çalıştığım otel, işimdeki başarılarımla gurur duyar. & 0,850 & & & \\
\hline Kaiser-Meyer Olkin Örneklem Yeterliliği (KMO) & \multicolumn{4}{|c|}{$\mathbf{0 , 8 1 0}$} \\
\hline Bartlett Küresellik Testi Ki Kare Değeri $\left(X^{2}\right)$ & \multicolumn{4}{|c|}{1259,253} \\
\hline Bartlett Küresellik Testi Anlamlılık Düzeyi & \multicolumn{4}{|c|}{$\mathbf{0 , 0 0 0}$} \\
\hline Faktör ve İfadeler & $\begin{array}{c}\text { Faktör } \\
\text { Yükü }\end{array}$ & Özdeğer & $\begin{array}{l}\text { Varyans } \\
(\%)\end{array}$ & $\begin{array}{c}\text { Cronbach's } \\
\text { Alpha }\end{array}$ \\
\hline Faktör 2: Örgütsel Özdeşleşme & & 3,980 & 66,336 & 0,895 \\
\hline $\begin{array}{l}\text { Birisi benim çalıştığım işletmeyi eleştirdiğinde, bunu } \\
\text { kişisel bir hakaret gibi hissederim. }\end{array}$ & 0,722 & & & \\
\hline $\begin{array}{l}\text { Başkalarının, çalıştığım otel hakkındaki düşünceleri } \\
\text { benim için önemlidir. }\end{array}$ & 0,801 & & & \\
\hline $\begin{array}{l}\text { Çalıştığım otel ile (işletmeyle) ilgili konuşurken, } \\
\text { genellikle "onlar" yerine "biz" derim. }\end{array}$ & 0,827 & & & \\
\hline Çalıştığım otelin başarısını, kendi başarım gibi görürüm. & 0,851 & & & \\
\hline $\begin{array}{l}\text { Birisi çalıştığım oteli övdüğünde, bunu kendime yapılmış } \\
\text { bir övgü olarak hissederim. }\end{array}$ & 0,849 & & & \\
\hline $\begin{array}{l}\text { Medyada, çalıştığım otel ile ilgili kötü bir haber çıkarsa, } \\
\text { üzüntü duyarım. }\end{array}$ & 0,830 & & & \\
\hline Kaiser-Meyer Olkin Örneklem Yeterliliği (KMO) & \multicolumn{4}{|c|}{$\mathbf{0 , 8 9 3}$} \\
\hline Bartlett Küresellik Testi Ki Kare Değeri $\left(X^{2}\right)$ & \multicolumn{4}{|c|}{1332,385} \\
\hline Bartlett Küresellik Testi Anlamlılık Düzeyi & \multicolumn{4}{|c|}{0,000} \\
\hline Faktör ve İfadeler & $\begin{array}{l}\text { Faktör } \\
\text { Yükü }\end{array}$ & Özdeğer & $\begin{array}{l}\text { Varyans } \\
(\%)\end{array}$ & $\begin{array}{l}\text { Cronbach's } \\
\text { Alpha }\end{array}$ \\
\hline Faktör 3: İşten Ayrılma Niyeti & & 2,622 & 87,388 & 0,927 \\
\hline Eğer imkânım olsaydı işimden ayrılırdım. & 0,920 & & & \\
\hline $\begin{array}{l}\text { Son bir yıl içerisinde işimden ayrılmayı daha sık } \\
\text { düşünmeye başladım. }\end{array}$ & 0,963 & & & \\
\hline Aktif olarak yeni bir iş arıyorum. & 0,921 & & & \\
\hline Kaiser-Meyer Olkin Örneklem Yeterliliği (KMO) & \multicolumn{4}{|c|}{0,713} \\
\hline Bartlett Küresellik Testi Ki Kare Değeri $\left(X^{2}\right)$ & \multicolumn{4}{|c|}{1025,921} \\
\hline Bartlett Küresellik Testi Anlamlılık Düzeyi & \multicolumn{4}{|c|}{$\mathbf{0 , 0 0 0}$} \\
\hline
\end{tabular}


Tablo 2: Ölçekler Arasındaki İlişkiyi Belirlemeye Yönelik Korelasyon Matrisi

\begin{tabular}{lccc}
\hline Ölçekler & $\begin{array}{c}\text { ÖRGÜTSEL } \\
\text { DESTEK }\end{array}$ & $\begin{array}{c}\text { ÖRGÜTSEL } \\
\text { ÖZDEŞLEŞME }\end{array}$ & $\begin{array}{c}\text { İŞTEN AYRILMA } \\
\text { NIYETI }\end{array}$ \\
\hline ÖRGÜTSEL DESTEK & $\mathbf{1}$ & $\ldots$ & $\ldots$ \\
\hline ÖRGÜTSEL ÖZDEŞLEŞME & $\mathbf{0 , 4 8 8 ^ { * * }}$ & $\mathbf{1}$ & $\ldots$ \\
\hline İŞTEN AYRILMA NIYETI & $\mathbf{- 0 , 6 1 6 * *}^{* *}$ & $\mathbf{- 0 , 3 2 6 * *}^{* *}$ & $\mathbf{1}$ \\
\hline
\end{tabular}

**: $P<0,001 \quad *: P<0,05$

Tablo 2' de algılanan örgütsel destek ile örgütsel özdeşleşme ve işten ayrılma niyeti arasındaki ilişkiyi belirlemek amacıyla yapılan basit korelasyon analizi sonuçları verilmiştir. Buna göre, Afyonkarahisar'daki beş yıldızlı otel işletmesi çalışanlarının algılanan örgütsel destek düzeyleri ile örgütsel özdeşleşme düzeyleri arasında $(r=0,488$; $p<0,001)$ orta düzeyde $(0,40<r<0,60)$ pozitif yönlü anlamlı bir ilişki olduğu saptanmıştır. Bu doğrultuda, araştırmanın temel hipotezi olan, $\mathbf{H}_{1}$ : "Beş yıldızlı otel işletmesi çalışanlarının örgütsel destek algılarn ile örgütsel özdeşleşme düzeyleri arasında pozitif yönlü ve anlamlı bir ilişki vardır." hipotezi desteklenmiştir.

Bununla birlikte, katılımcıların algılanan örgütsel destek düzeyleri ile işten ayrılma niyeti arasında $(r=-0,616 ; p<0,001)$ yüksek düzeyde $(0,60<r<0,80)$ negatif yönlü bir ilişki olduğu belirlenmiştir. Bu doğrultuda, araştırmanın temel hipotezlerinden biri olan, $\mathbf{H}_{2}$ : "Beş yıldızlı otel işletmesi çalı̧̧anlarının örgütsel destek algıları ile işten ayrılma niyetleri arasında negatif yönlü ve anlamlı bir ilişki vardır." hipotezinin desteklendiği tespit edilmiştir.

Tablo 3. Algılanan Örgütsel Desteğin Örgütsel Özdeşleşme Üzerindeki Etkisi

\begin{tabular}{|c|c|c|c|c|c|c|c|}
\hline \multirow{2}{*}{$\begin{array}{l}\text { Bağımsız } \\
\text { Değişkenler }\end{array}$} & \multicolumn{3}{|c|}{ Standardize Edilmemiş Standardize Edilmiş } & \multirow[t]{2}{*}{$\mathbf{t}$} & \multirow[t]{2}{*}{ Sig. } & \multirow{2}{*}{$\underset{\text { Değeri }}{F}$} & \multirow[t]{2}{*}{ Sig. } \\
\hline & B & s.s. & Beta & & & & \\
\hline Sabit & 1,769 & 0,187 & --- & 9,477 & 0,000 & & \\
\hline $\begin{array}{l}\text { ÖRGÜTSEL } \\
\text { DESTEK }\end{array}$ & $0,570 * *$ & 0,051 & 0,488 & 11,251 & 0,000 & 120,500 & \\
\hline
\end{tabular}

Sig.: anlamlılık düzeyi (p), ${ }^{* *} \mathrm{p}<0,001$ düzeyinde ilişkiler anlamlıdır, n: 407.

Sökmen ve diğerleri (2015) tarafından yapılan çalışmada da benzer bulgular olduğu tespit edilmiştir. Buna göre, algılanan örgütsel desteğin örgütsel özdeşleşme ile arasında pozitif yönlü ve anlamlı düzeyde bir ilişki bulunduğu belirtilmiştir.

Bununla birlikte, Anafarta (2015) tarafından yapılan çalışma sonucunda algılanan örgütsel destek ile işten ayrılma niyeti arasında ise orta derecede, negatif $(r=-0,468)$ yönlü ve anlamlı bir ilişki bulunmuştur. Koçak ve Yücel (2018) tarafından yapılan araştırmada da algılanan örgütsel destek ile işten ayrılma niyeti arasında \%99 önem düzeyinde orta derecede negatif yönlü ve anlamlı bir ilişki olduğu görülmüştür $(r=-0,435 ; p=0,001)$. Bu da bu çalışmada elde edilen sonuçları destekler niteliktedir.

Örgütsel özdeşleşmenin bağımlı değişken ve örgütsel destek algısının ise bağımsız değişken olarak ele alındığı ve etkisinin açıklanması için yapılan basit doğrusal regresyon analizi sonuçları tablo 3 'te 
sunulmuştur. Yapılan analiz sonucunda değişkenler arasındaki doğrusal regresyon modelinin anlamlı olduğu tespit edilmiştir $(F=126,580 ; p<0,001)$. Buna göre regresyon modeli şu şekilde kurulabilir.

\section{Örgütsel Özdeşleşme = 1,769 + 0,570* Örgütsel Destek Alg1sı}

Bu modele göre, örgütsel destek algısında meydana gelen bir (1) birimlik artış örgütsel özdeşleşme düzeyinde 0,570 birimlik bir artışa sebep olmaktadır.

Sökmen vd. (2015) tarafından yapılan çalışmada da benzer bulgular elde edilmiştir. Çalışmada, algılanan örgütsel destek değişkeni ile örgütsel özdeşleşme arasında pozitif yönlü ve anlamlı bir etkisi olduğu tespit edilmiştir. Turunç ve Çelik (2010) çalışanların algıladıkları örgütsel desteğin örgütsel özdeşleşme üzerine etkisini belirlemek için yaptıkları araştırma sonucunda algılanan örgütsel desteğin örgütsel özdeşleşme düzeylerini pozitif ve anlamlı olarak etkilediğini ifade etmişlerdir. Diğer bir değişle, yaptıkları analiz sonucunda çalışanların algıladıkları örgütsel desteğin örgütsel özdeşleşme düzeyini anlamlı olarak artırdığını aktarmışlardır.

Tablo 4'de yer alan algılanan örgütsel desteğin örgütsel özdeşleşme üzerine etkisini belirlemek amaciyla yapılan basit regresyon analizi sonuçlarına göre algılanan örgütsel destek bağımsız değişken, işten ayrılma niyeti ise bağımsız değişkendir.

Tablo 4. Algılanan Örgütsel Desteğin İşten Ayrılma Niyeti Üzerindeki Etkisi

\begin{tabular}{|c|c|c|c|c|c|c|c|}
\hline \multirow{3}{*}{$\begin{array}{l}\text { Bağımsız } \\
\text { Değişkenler }\end{array}$} & \multicolumn{3}{|c|}{ Standardize Edilmemiş Standardize Edilmiş } & \multirow{3}{*}{$\mathbf{t}$} & \multirow{3}{*}{ Sig. } & \multirow{3}{*}{$\underset{\text { Değeri }}{F}$} & \multirow{3}{*}{ Sig. } \\
\hline & \multicolumn{2}{|c|}{ Katsayılar } & Katsayılar & & & & \\
\hline & $\mathbf{B}$ & S.S. & Beta & & & & \\
\hline Sabit & 5,496 & 0,219 & --- & 25,098 & 0,000 & & \\
\hline $\begin{array}{l}\text { ÖRGÜTSEL } \\
\text { DESTEK }\end{array}$ & $-0,936 * *$ & 0,059 & $-0,616$ & $\begin{array}{c}- \\
15,738\end{array}$ & 0,000 & & \\
\hline
\end{tabular}

Sig.: anlamlılık düzeyi (p), ${ }^{* *} \mathrm{p}<0,001$ düzeyinde ilişkiler anlamlıdır, n: 407.

Yapılan analiz sonucunda değişkenler arasındaki doğrusal regresyon modelinin anlamlı olduğu tespit edilmiştir ( $\mathrm{F}=247,681 ; \mathrm{p}<0,001)$. Buna göre algılanan örgütsel desteğin işten ayrılma niyeti üzerindeki etkisini belirleme amacına yönelik regresyon modeli şu şekildedir:

\section{İşten Ayrılma Niyeti= 5,496 + $(-0,936)^{*}$ Örgütsel Destek Algısı}

$\mathrm{Bu}$ regresyon modeline göre, örgütsel destek algısında gerçekleşen her 1 (bir) birimlik artış, işten ayrılma niyeti üzerinde -0,936'lik bir azalış meydana getireceği tespit edilmiştir.

İlgili literatür incelendiğinde benzer bulgular elde edildiği elde edilmiştir. Buna göre, Anafarta (2015) tarafından yapılan çalışmada algılanan örgütsel desteğin işten ayrılma niyeti üzerine negatif yönlü bir etkisinin olduğu, Koçak ve Yücel (2018) tarafından yapılan araştırma sonucunda algılanan örgütsel destek ile işten ayrılma niyeti arasında negatif yönlü anlamlı bir ilişki olduğu ve Bağdoğan'nın (2018) bankacılık sektörü çalışanları üzerine yaptıği çalışmasında algılanan örgütsel destek ile işten ayrılma niyeti arasında negatif ve anlamlı bir ilişki olduğu tespit edilmiştir. 


\section{SONUÇ VE DEĞERLENDİRME}

Beş yıldızlı otel işletmeleri çalışanlarının örgütsel destek algılarının örgütsel özdeşleşme ve işten ayrılma niyetine etkisinin belirlenmesinin amaçlandığı bu araştırmada, algılanan örgütsel destek, örgütsel özdeşleşme ve işten ayrılma niyetine ilişkin ilgili literatür incelenmiş ve Afyonkarahisar'da faaliyet gösteren beş yıldızlı otel işletmeleri çalışanları üzerinde uygulama yapılmıştır. Bu çerçevede elde edilen sonuçlar şu şekilde belirtilebilir.

Beş yıldızlı otel işletmesi çalışanlarının algılanan örgütsel destek ile örgütsel özdeşleşme ve işten ayrılma niyeti arasındaki ilişkiyi belirlemek amacıyla yapılan basit korelasyon analizi sonuçlarına göre çalışanların algılanan örgütsel destek düzeyleri ile örgütsel özdeşleşme düzeyleri arasında orta düzeyde pozitif yönlü anlamlı bir ilişki olduğu saptanmıştır. Bununla birlikte, katılımcıların algılanan örgütsel destek düzeyleri ile işten ayrılma niyeti arasında ise yüksek düzeyde negatif yönlü anlamlı bir ilişki olduğu tespit edilmiştir.

Afyonkarahisar'da faaliyet gösteren beş yıldızlı otel işletmeleri çalışanlarının örgütsel destek algılarının örgütsel özdeşleşme düzeylerine etkisini belirlemek amacıyla yapılan basit doğrusal regresyon analizi sonucunda değişkenler arasındaki doğrusal regresyon modelinin anlamlı olduğu tespit edilmiştir. Bu modele göre, örgütsel destek algısında meydana gelen bir (1) birimlik artış örgütsel özdeşleşme düzeyinde 0,570 birimlik bir artışa sebep olduğu tespit edilmiştir. Bununla birlikte, beş yıldızlı otel işletmeleri çalışanlarının örgütsel destek algılarının işten ayrılma niyetlerine etkisini belirlemek amacıyla yapılan basit doğrusal regresyon analizi sonucunda değişkenler arasındaki doğrusal regresyon modelinin anlamlı olduğu belirlenmiştir. Bu regresyon modeline göre, örgütsel destek algısında gerçekleşen her 1 (bir) birimlik artış, işten ayrılma niyeti üzerinde 0,936'lik bir azalış meydana getireceği görülmüştür.

Araştırmada elde edilen bulgular neticesinde şu öneriler sunulabilir:

- Otel işletmeleri çalışanlarının örgütsel destek algılarının düşmesine neden olan unsurları tespit ederek gerekli önlemlerin alınması sağlanmalıdır.

- Otellerin, çalışanlarını bir değer kabul etmesi, onları önemsemesi ve en önemlisi bunları çalışanlarına göstermesi, çalışanların örgüt ile olan duygusal ilişkilerini olumlu yönde etkilemektedir. Dolayısıyla da bu tür çalışanların iş tatmin düzeylerinin ve performanslarının daha yüksek olacağı ve otel işletmelerinin amaçları için daha çok çalışacağı söylenebilir.

- Beş yıldızlı otel işletmesi çalışanlarının örgütsel destek algılarının örgütsel özdeşleşme düzeyleri üzerine pozitif yönlü ve anlamlı bir etkisi olduğu tespit edilmiştir. Bu nedenle otel işletmesi çalışanlarının örgütsel destek algısının yükselmesi çalışanların örgütsel özdeşleşme düzeylerini de arttıracağından dolayı çalışanlara örgütsel destek algısını arttırmak için örgütsel adaleti sağlamak, yöneticiler tarafından destek verilmesi gibi unsurların gerçekleştirilmesi gerekmektedir. Bu nedenle terfi konusunda adil davranılması, iş yükü ve ücretlendirme konusunda adil olunması çalışanların örgütsel özdeşleşme düzeylerinin artmasına sebep olabilecektir.

- Bu çalışmada elde edilen bulgulara göre algılanan örgütsel destek algısı işgörenlerde arttığı zaman işten ayrılma niyeti de azalmaktadır. Bu nedenle işgörenlere örgütsel destek vererek veya bu yönde olumlu algılamalar yaratılarak işten ayrılma niyetinin azaltılması çalışılmalıdır. Bu aşamada çalışanlara iş güvenliği sağlamak, takdir etmek, örgüt içi güçlü bir iletişim kurmak gibi davranışlar siralanabilir.

$\mathrm{Bu}$ araştırmanın sonucunda çalışma bulgu ve sonuçları özellikle de termalin başkenti olan Afyonkarahisar' da faaliyet gösteren beş yıldızlı otel işletmelerindeki durumu tespit etmek açısından önemli olmuştur. Bununla birlikte, konunun diğer sektörler açısından veya farklı turizm destinasyonları açısından ele alınması da farklı sonuçların çıkabilmesine ve karşılaştırma yapılabilmesine imkan sağlayabilecektir. 


\section{KAYNAKÇA}

Akgül, A. ve Çevik, Ç. (2003). İstatistiksel Analiz Teknikleri. Emek Ofset Baskı.

Akın, M. (2008). Örgütsel Destek, Sosyal Destek ve İş-Aile Çatışmalarının Yaşam Tatmini Üzerindeki Etkileri, Erciyes Üniversitesi Sosyal Bilimler Enstitüsü Dergisi, 25: 141-170.

Akşit Aşık, N. (2017). Otel Çalışanlarının Sosyotropik ve Otonomik Kişilik Özelliklerinin Örgütsel Özdeşleşme Düzeylerine Etkisi, Journal of Tourism and Gastronomy Studies, 5(3): 288-302.

Akoğlan Kozak, M. (2012). Otel İşletmelerinde İnsan Kaynakları Yönetimi ve Örnek Olaylar. (4. Baskı), Ankara: Detay Yayıncilı.

Akyüz, M. ve Dalkılıç Yılmaz, F. (2015). Konaklama İşletmelerinde Örgütsel Özdeşleşme ve Örgütsel İletişimin İşgörenlerin İşten Ayrılma Niyetine Etkisi, Kastamonu Üniversitesi İktisadi ve İdari Bilimler Fakültesi Dergisi, 8: 137-143.

Allen, W. M., Armstrong, J. D., Reid, F. M. and Riemenschneider, K. C. (2008). Factors Impacting the Perceived Organizational Support of IT Employees, Information \& Management, 45: 556-563.

Aliyev, Y. ve Işık, M. (2014). Örgütsel Sosyalleşme ve Örgütsel Özdeşleşme Arasındaki İlişki: Bir Araştırma, Sosyal Bilimler Enstitüsü Dergisi, 37: 131-149.

Anafarta, N. (2015). Algılanan Örgütsel Destek ve İşten Ayrılma Niyeti İlişkisi: İş Tatmininin Aracılık Rolü, İ.Ü İşletme Fakültesi İşletme İktisadi Enstitüsü Yönetim Dergisi, 26 (79): 112-130.

Avcı, N. ve Küçükusta, D. (2009). Konaklama İşletmelerinde Örgütsel Öğrenme, Örgütsel Bağl1lık ve İşten Ayrılma Eğilimi Arasındaki İlişki, Anatolia: Turizm Araştırmaları Dergisi, 20(1): 33-44.

Bağdoğan Yıldız, S. (2018). Algılanan Örgütsel Destek, Psikolojik İyi Oluş ve İşten Ayrılma Niyeti Arasındaki İlişkilerin Değerlendirilmesi, İş, Güç: Endüstri İlişkileri ve İnsan Kaynakları Dergisi, 20(3): $5-20$.

Bal, Ş. (2018). Otel İşletmelerinde Algllanan Örgütsel Destek ve Örgüte Uyum Düzeyinin Algılanan Hizmet Performansı Üzerindeki Etkisi: Ankara İli Örneği, Yayınlanmamış Yüksek Lisans Tezi, Afyon Kocatepe Üniversitesi, Afyon.

Bhattacharya, B. C. and Elsbach, K. D. (2002). Us Versus Them: The Roles of Organizational Identification and Disidentification in Social Marketing Initiatives, Journal of Public PolicyE Marketing, 21(1): 26- 36.

Boessenkool, J., Leisink, P. and Verweel, P. (2003). Chapter 2: Commitment and Community in Organizations, (Ed.) W. Koot, P. Leisink and P. Verweel, in Organizational Relationships in the Networking Age: The Dynamics of Identity Formation and Bonding. UK: Edward Elgar Publishing.

Boz, M., Özkan, Ç. ve Aydın, Ş. (2017). Algılanan Örgütsel Desteğin Örgütsel Bağlllı̆ga Etkisi: Otelcilik Sektöründe Bir Araştırma, 16. UіK Özel Sayısı, 71: 72-84.

Cammann, C., Fichman, M., Jenkins, D. and Klesh, J. (1979). Michigan Organizational Assessment Questionnaire. Michigan: University of Michigan, Ann Arbor,

Cheung, M. F. Y. and Law, M. C. C. (2008). Relationships of Organizational Justice and Organizational Identification: The Mediating Effects of Perceived Organizational Support in Hong Kong, Asia Pacific Business Review, 14(2): 213-231.

Çekmecelioğlu, H. (2006). İş Tatmini ve Örgütsel Bağlılık Tutumlarının İşten Ayrılma Niyeti ve Verimlilik Üzerindeki Etkilerinin Değerlendirilmesi Bir Araştırma, İş-Güç- Endüstri İlişkileri ve İnsan Kaynakları Dergisi, 8(2): 153-168. 
Dawley, D., Houghton, J., and Bucklew, N. (2010). Perceived Organizational Support and Turnover Intention: The Mediating Effects of Personal Sacrifice and Job Fit, The Journal of Social Psychology, 150(3): 238-257.

Dutton, J. E., Dukerich, J. M. and Harquail C. V. (1994). Organizational Images and Member Identifications, Administrative Science Quarterly, 39: 239- 263.

Edwards, M. R. and Peccei, R. (2010). Perceived Organizational Support, Organizational Identification, and Employee Outcomes, Journal of Personnel Psychology, 9(1): 17- 26.

Ekmekci, Ö. and Casey, A. (2009). How Time Brings Together "I" and "We": A Theory of Identification Through Memory. Journal of Behavioral and Applied Management, 11(1): 48-67.

Ekmekçioğlu, E. M. ve Sökmen, A. (2016). Algılanan Örgütsel Desteğin İşten Ayrılma Niyetine Etkisinde Örgütsel Bağlılığın Aracı Rolü: Sınır Birimi Çalışanları Üzerine Bir Araştırma, International Review of Economics and Management, 4(2): 32-45.

Eisenberger, R., Hungtington, R., Hutchison, S. and Sowa, D. (1986). Perceived Organizational Support, Journal of Applied Psychology, 71: 500-507.

Erdoğan, Y., Bayram, S. ve Deniz, L. (2007). Web Tabanlı Öğretim Tutum Ölçeği: Açıklayıcı ve Doğrulayıcı Faktör Analizi Çalışması, Uluslararası İnsan Bilimleri Dergisi, 4(2): 1-14.

Gibney, R., Zagenczyk, T. J., Fuller, J. B., Hester, K. and Caner, T. (2011). Exploring Organizational Obstruction and the Expanded Model of Organizational Identification, Journal of Applied Social Psychology, 4(5): 1083-1109.

Giray D. (2013). İş Yeri Desteği: Örgüt, Yönetici ve Çalışma Arkadaşları Desteğine Genel Bir Bakış, İş-Güç Endüstri İlişkileri ve İnsan Kaynakları Dergisi, 15(3): 65-81.

Gülertekin, S. (2013). Duygu İklimi ve Liderlik Tarzının İşten Ayrlma Niyetine Etkileri: Alanya'daki Turizm İşletmelerine Yönelik Bir Araştırma, Yayımlanmamış Yüksek Lisans Tezi, Çanakkale Onsekiz Mart Üniversitesi, Çanakkale.

Güney, S., Akalın, Ç. ve İlsev, A. (2007). Duygusal Örgütsel Bağlllık Gelişiminde Algılanan Örgütsel Destek ve Örgüt Temelli Öz-Saygı, H.Ü. İktisadi ve İdari Bilimler Fakültesi Dergisi, 25(2): 189-211.

Hellman, C. M., Fuqua, D. R. and Worley, J. (2006). A Reliability Generalization Study on the Survey of Perceived Organizational Support the Effects of Mean Age and Number of Items on Score Reliability, Educational and Psychological Measurement, 66(4): 631- 642.

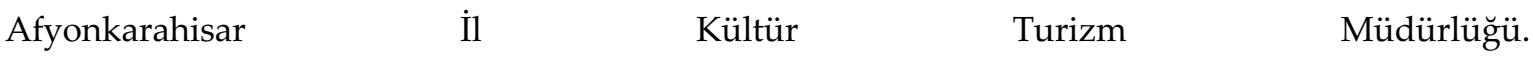
http://www.afyonkulturturizm.gov.tr/TR,158749/kultur-turizm-istatistikleri.html> [Erişim: 01.06.2018].

Immordino, M. K. (2010). Organizational Assessment and Improvement in the Public Sector. USA: CRC Press.

İşçi, E. (2010). İşten Ayrılma ve Etkileyen Unsurlar. [Online] http://emreisci. blogspot.com. tr/2010/10/isten-ayrilma-ve-etkileyen unsurlar.html> [Erişim tarihi: 20 Aralık 2018].

Kaplan, M. ve Öğüt, A. (2012). Algılanan Örgütsel Destek ile Örgütsel Bağlllık Arasındaki İlişkinin Analizi: Otel İşletmelerinde Bir Uygulama, Süleyman Demirel Üniversitesi İktisadi ve İdari Bilimler Fakültesi Dergisi, 17(1): 387-401.

Karabey, C. N. ve İşçan, Ö. F. (2007). Örgütsel Özdeşleşme, Örgütsel İmaj ve Örgütsel Vatandaşlık Davranışı İlişkisi: Bir Uygulama, Atatürk Üniversitesi İktisadi ve İdari Bilimler Fakültesi Dergisi, 21(2): 231-241. 
Katrinli, A., Atabay, G., Günay, G., and Güneri B. (2008). Leader-Member Exchange, Organizational Identification and the Mediating Role of Job Involvement for Nurses, Journal of Advanced Nursing, 64(4): 354-362.

Kaya, B. (2012). Algılanan Örgütsel Destek Düzeyinin ve Çalışanların Kariyer Tatmininin İşten Ayrılma Niyeti Üzerindeki Etkileri: Konaklama İşletmelerinde Bir Uygulama, Yayınlanmamış Yüksek Lisans Tezi, Akdeniz Üniversitesi, Antalya.

Koçak, D. ve Yücel, İ. (2018). Algılanan Örgütsel Destek ile İşten Ayrılma Niyeti Arasındaki İlişkide Duygusal Bağlılı̆̆ın Aracı Etkisinin İncelenmesi, Atatürk Üniversitesi İktisadi ve İdari Bilimler Dergisi, 32(3): 683-704.

Kreiner, G. E. and Ashforth B. E. (2004). Evidence Toward an Expanded Model of Organizational Identification, Journal of Organizational Behavior, 25: 1-27.

Kültür ve Turizm Bakanlığı. (1989). Otelcilik ve Turizm Endüstrisinde İsgücü Araştırması. Ankara.

Mael, F.A and Ashforth, B.E. (1992). Alumni and Their Alma Mater: A Partial Test of The Reformulated Model of Organizational Identification, Journal of Organiational Behavior, 13: 103-123.

Onay, M. ve Kılcı, S. (2011). İş Stresi ve Tükenmişlik Duygusunun İşten Ayrılma Niyeti Üzerine Etkileri: Garsonlar ve Aş̧̧ıbaşlar, Organizasyon ve Yönetim Bilimleri Dergisi, 3(2): 363-372.

Özdevecioğlu M. (2003). Algılanan Örgütsel Destek ile Örgütsel Bağlllık Arasındaki İlişkilerin Belirlenmesine Yönelik Bir Araştırma, Dokuz Eylül Üniversitesi İktisadi ve İdari Bilimler Fakültesi Dergisi, 18(2): 113- 130.

Özdevecioğlu, M. (2004). Algılanan Örgütsel Desteğin İşten Ayrılma Niyeti Üzerindeki Etkileri, Amme İdaresi Dergisi, 37(4): 97-115.

Pelit, E. (2008). İşletmelerde İşgören Güçlendirmenin İşgörenlerin İş Doyumuna Etkisi: Otel Isşletmelerinde Bir Araştırma, Yayımlanmamış Doktora Tezi, Gazi Üniversitesi, Ankara.

Polat, M. (2009). Örgütsel Özdeşleşmenin Öncülleri ve Ardılları Üzerine Bir Saha Çalı̧ması, Yayınlanmamış Doktora Tezi, Uludağ Üniversitesi, Bursa.

Rhoades, L. and Eisenberger, R. (2002). Perceived Organizational Support: A Review of the Literature, Journal of Applied Psychology, 87(4): 698-714.

Sabuncuoğlu, E. T. (2007). Eğitim, Örgütsel Bağlllık ve İşten Ayrılma Niyeti Arasındaki İlişkilerin İncelenmesi, Ege Akademik Bakış, 7(2): 613-628.

Solnet, D. (2006). Introducing Employee Social Identification to Customer Satisfaction Research: A Hotel Industry Study, Managing Service Quality: An International Journal, 16(6): 575-594.

Sökmen, A., Ekmekçioğlu, E.B. ve Çelik, K. (2015). Algılanan Örgütsel Destek, Örgütsel Özdeşleşme ve Yönetici Etik Davranışı İlişkisi: Araştırma Görevlilerine Yönelik Araştırma, İşletme Araştırmaları Dergisi, 7(1): 125-144.

Tuna, M. ve Yeşiltaş, M. (2014). Etik İklim, İşe Yabancılaşma ve Örgütsel Özdeşleşmenin İşten Ayrılma Niyeti Üzerindeki Etkisi: Otel İşletmelerinde Bir Araştırma, Anatolia: Turizm Araştırmaları Dergisi, 25(1): 105-117.

Turunç, Ö. ve Çelik, M. (2010). Çalışanların Algıladıkları Örgütsel Destek ve İş Stresinin Örgütsel Özdeşleşme ve İş Performansına Etkisi, Yönetim ve Ekonomi: Celal Bayar Üniversitesi İktisadi ve İdari Bilimler Fakültesi Dergisi, 17 (2): 183-206.

Turunç, Ö. ve Avcı, U. (2015). Algılanan Örgütsel Destek ve Lider-Üye Etkileşiminin İşten Ayrılma Niyeti Üzerindeki Etkisi: İş Stresinin Aracllık Rolü, Seyahat ve Otel İşletmeciliği Dergisi, 12 (1): 43-63. 
Tutar, H. (2013). İ̧̧letme \& Yönetim Terimleri Ansiklopedi Sözlük (Konu Anlatımlı). Ankara: Detay Yayıncilik.

Tüzün, İ. and Kalemci, R. (2012). Organizational and Supervisory Support in Relation to Employee Turnover Intentions, Journal of Managerial Psychology, 27(5): 518-534.

Ural, A. ve Kılıç, İ. (2011). Bilimsel Araştırma Süreci ve Spss ile Veri Analizi. Ankara: Detay Yayıncılık.

Uzun, T. (2018). Öğretmenlerin Algıladığı Örgütsel Destek ile Örgütsel Özdeşleşme ve İşten Ayrılma Niyeti Arasındaki İlişki: Örgütsel Güvenin Aracı Rolü, Karadeniz Sosyal Bilimler Dergisi, 10(18): 133155.

Wang, G. and Netemeyer, R. G. (2002). The Effects of Job Autonomy, Customer Demandingness, and Trait Competitiveness on Salesperson Learning, Self-Efficacy, and Performance, Journal of The Academy of Marketing Science, 30(3): 217-228.

Wiesenfeld, B. M., Raghuram, S. and Garud, R. (1999). Communication Patterns as Determinants of Organizational Identification in a Virtual Organization, Organization Science, 10(6): 777-790.

Yarmacı, N. (2012). Psikolojik Güçlendirmenin Örgütsel Özdeşlemeye Etkisi: Otel İşletmelerinde Bir Araştırma, Yayınlanmamış Yüksek Lisans Tezi, Afyon Kocatepe Üniversitesi, Afyonkarahisar.

Yeşiltaş, M. (2012). Örgütsel Özdeşleşmenin Oluşmasında Belirleyiciler Olarak Etik Liderlik ve Etik İklim: Otel İşletmelerine Yönelik Bir Uygulama, Yayınlanmamış Doktora Tezi, Gazi Üniversitesi, Ankara.

Yıldırım, M. H., Erul, E. E. ve Kelebek, P. (2014). Tükenmişlik ile İşten Ayrılma Niyeti Arasındaki İlişki Banka Çalışanları Üzerine Bir Araştırma, Organizasyon ve Yönetim Bilimleri Dergisi, 6(1): 34-44.

Yıldız, S., Savcı, G. ve Kapu, H. (2014). Motive Edici Faktörlerin Çalışanların İş Performansına ve İşten Ayrılma Niyetine Etkisi, Yönetim ve Ekonomi: Celal Bayar Üniversitesi İktisadi ve İdari Bilimler Fakültesi Dergisi, 21(1): 233- 249.

Yılmaz, H. ve Görmüş, A. Ş. (2012). Stratejik Girişimciliğin, Algılanan Örgütsel Destek ve Örgütsel Öğrenme Üzerine Etkilerinin Araştırılması: Tekstil Sektöründe Ampirik Bir Çalışma, Journal of Yaşar University, 26(7): 4483 - 4504.

Yılmaz, A. (2016). Algılanan Örgütsel Destek Ortamında İş Stresi ve İş Yaşam Kalitesinin İş Performansı Üzerine Etkisinin Araştııılması: İstanbul'da Bulunan Beş Yıldızlı Otellerde Çalışan Aşçılar Üzerine Bir Araştırma, Yayınlanmamış Doktora Tezi, İstanbul Üniversitesi, İstanbul.

Yüksel, İ. (2006). Örgütsel Destek Algısı ve Belirleyicilerinin İşten Ayrılma Eğilimi ile İlişkisi, İstanbul Üniversitesi İşletme Fakültesi Dergisi, 35(1): 7-32. 